\title{
Integrating socio-economic and biophysical data to support water allocations within river basins: An example from the Inkomati Water Management Area in South Africa
}

\author{
W.J. de Lange ${ }^{1}$, R.M. Wise ${ }^{1}$, G.G. Forsyth ${ }^{2}$, and A. Nahman ${ }^{1 *}$ \\ ${ }^{1}$ Environmental and Resource Economics Group, Council for Scientific and Industrial Research, \\ PO Box 320, Stellenbosch, 7599, South Africa \\ ${ }^{2}$ Biodiversity and Ecosystems Services Group, Council for Scientific and Industrial Research, \\ PO Box 320, Stellenbosch, 7599, South Africa \\ *Corresponding author (Tel: +27(0)21 888 2403; fax: +27(0)21 886 6518; e-mail: \\ anahman@csir.co.za)
}

\begin{abstract}
Sustainable natural resource management requires inputs from both the natural and the social sciences. Since natural and social systems are inter-related and inter-dependent, it is essential that these data can be integrated within a given analysis, which requires that they are spatially compatible. However, existing environmental and socio-economic monitoring networks tend to observe, collect and report socio-economic and biophysical data separately; with the result that much of these data are spatially incompatible, adding to the complexity of objective and consistent resource management. We present an approach for overcoming spatial incompatibilities between socio-economic and biophysical data; based on a meta-modelling approach using Geographical Information Systems and an application of a water-use simulation model. The method is developed and applied to the irrigation agriculture sector in the Inkomati Water Management Area in South Africa. Agricultural
\end{abstract}


census data, which is measured on a magisterial district scale, is integrated with georeferenced land cover data, which is independent of political boundaries. This allows us to increase the resolution at which data on the economic value derived from irrigation water is presented, from coarse magisterial district scale to a finer $\left(49 \mathrm{~km}^{2}\right)$ 'meso-zone' scale, enabling more efficient allocations of irrigation water within magisterial districts.

Keywords: water allocation decision making; Geographical Information Systems; metamodelling; data integration; spatial analysis; river basins; Inkomati Water Management Area 


\section{Introduction}

Interactions between social and natural systems involve complexities that constrain the ability of society to keep development and growth within the natural limits of ecosystems (Goodstein, 1999; 2000). Three of the more obvious of these complexities include: a) understanding and accounting for the natural limits of ecosystems and the constraints to development and growth that these imply (Costanza and Daly, 1992); b) valuing and internalising the unaccounted for impacts of environmental degradation (Heal, 2000); and c) recognising and dealing with the spatial heterogeneity of landscapes (Eade and Moran, 1996; Bruggeman et al., 2005). While the disciplines of ecological economics and environmental economics have developed and applied theoretical and methodological frameworks to address the first two of these challenges ${ }^{1}$, this study focuses on the third challenge, which has thus far received more limited attention.

In the face of rapidly declining stocks of natural capital and flows of ecosystem services due to unprecedented rates of land-use change, increasing water scarcity, and changing climates; natural-resource managers and environmental-policy makers are in desperate need of spatially accurate and relevant policy and management advice (Curtis et al., 2003; Ruth, 2006). This information should be in the form of quantified tradeoffs between social, ecological and economic objectives across a landscape. This advice is needed to inform and support initiatives that: 1) increase the equity, effectiveness and/or efficiency of resource use by revealing information on the sources and drivers of change, and the economic and

\footnotetext{
${ }^{1}$ The 'sustainomics' framework developed by Munasinghe (2002), for example, attempts to address the first complexity by tempering the traditional, narrow, utility-maximisation approaches of economics with social and ecological sustainability criteria, in order to account for the overall resilience and robustness of natural and social systems. The second complexity is continually being addressed through the development and application of economic-valuation techniques (discussed and evaluated by, among others, Sinden and Griffith (2007) and Turner et al. (2003)); and more recently using discourse-based approaches (Wilson and Howarth, 2002).
} 
social values generated (e.g., Jakeman and Letcher (2003)); 2) improve the management and protection of existing conservation areas and expand existing protected area networks to increase resilience to climate change (Reyers et al., under review); and 3) aim to introduce incentive-based mechanisms (such as payments for ecosystem services) for ecosystem conservation and management (Blignaut et al., 2008). For policy and management advice to effectively promote sustainability, it needs to account for the effects of varied topography and biophysical processes driving socio-economic patterns across large heterogeneous areas. Such advice can only be provided if the socio-economic and biophysical data can be integrated and analysed together.

The need to understand and address heterogeneity in the distribution of, and relationships between, human and ecological variables across landscapes is well recognised in the natural sciences (e.g. geography and ecology), which are concerned with understanding and modelling the causes and consequences of land-use changes over space and time (Irwin and Geoghegan, 2001; Van Delden et al., 2007). The importance of space in influencing human behaviour is also acknowledged and accounted for in economic-related disciplines. For example, the travel-cost method accounts for the effect of distance on recreational demand (Tobias and Mendelsohn, 1991), while hedonic models reveal the effect of location on property prices (Freeman, 1979). In fact, the first 'spatial economics' was driven in the late 1970's by researchers working on urban and regional econometric models to understand variations in income and expenditure and to determine optimal solutions for associated investment activities (Bateman et al., 2002). The techniques that were developed spread to mainstream economics during the 1980s and early 1990s (e.g., Anselin, 1988).

Advances in remote sensing and other spatial technologies have increased the ability of researchers to conceptualise and analyse the geographical and environmental processes 
associated with different land-use patterns (Irwin and Geoghegan, 2001). This has led to a rise in the use of GIS applications within the applied environmental economics literature (Bateman et al., 2002). Applications of GIS in environmental economics include analysing the conversion of land parcels from agricultural to residential uses (Irwin and Geoghegan, 2001); analysing deforestation (Geoghegan et al., 2001; Irwin and Geoghegan, 2001); and understanding the spatial contexts (habitat, land cover) that drive natural processes like nutrient cycling (Bockstael, 1996; Wadsworth and Treweek, 1999). These early efforts, however, have received considerable criticism regarding their unrealistic spatial assumptions (Lovett and Bateman, 2001; Bateman et al., 2002). More complex, spatially explicit studies at the landscape scale, in which biophysical and socio-economic data are integrated and analysed using computer simulation models, have been undertaken more recently (Jakeman and Letcher, 2003; Hean et al., 2006). However, these analyses, and the data used, are simulated rather than spatially referenced. Consequently, they are not impeded by the practical problems of integrating and mapping socio-economic and biophysical data types, as described in this paper.

Spatially-explicit social-ecological analyses are difficult because of the different scales at which socio-economic and biophysical data are collected and reported, the different units of measurement used for social and biophysical data, and the fact that the boundaries of biophysical and socio-economic variables do not coincide (Herr, 2007). Socio-economic data are generally reported at a coarse (administrative boundary) scale (even if data are collected at household level, these are normally aggregated) and tend not to be spatially referenced at finer scales. Consequently, the exact locations of socio-economic variables within an administrative area are often not readily available, if at all, and the entire area tends to be allocated a single value for these variables, irrespective of the heterogeneity within that area. The aggregation of data in this way often limits its usefulness and 
reliability (depending on the problem at hand), and precludes opportunities for more detailed analysis within the area. It also makes comparison with bio-physical variables, which are reported at higher resolutions, challenging. Biophysical variables, on the other hand, are almost always spatially referenced, because this is an essential characteristic of these variables and because the techniques for collecting these data (e.g., remote sensing) allow for this. Further, the boundaries delimiting biophysical phenomena (natural boundaries) are invariably different from those delimiting socio-economic areas (artificial boundaries), which makes overlaying these data within a GIS environment challenging.

In this paper we present a methodological approach for overcoming spatial incompatibilities between socio-economic and biophysical data (temporal incompatibilities are not addressed). The method is developed using agricultural-economic census data (not spatially referenced) and geo-referenced biophysical data (land cover) for the Inkomati Water Management Area in South Africa. This is an administrative area that covers the South African portion of the Inkomati River Basin (Figure 1). More particularly, the methodology involves the transformation of gross economic values of water (as derived from its productive use in commercial irrigation agriculture), which vary across the landscape but are not spatially referenced, into a spatially-referenced GIS data layer compatible with existing biophysical data layers. The methodology is based on a metamodelling approach using a Geo-spatial Analysis Platform (GAP) (Council for Scientific and Industrial Research et al., 2007), described in Box 1, and an application of the 'South African Procedure for estimating irrigation WAter requiremenTs' (SAPWAT) simulation model (Crosby, 1996). The development of the modelling approach is described, and the results generated from its application are presented and discussed. The usefulness and relevance of such an approach to natural-resource managers and policy makers in South Africa and elsewhere are discussed, along with recommendations for future research. 


\section{BOX 1: The South Africa Geo-spatial Analysis Platform (GAP)}

GAP was developed specifically to address the problem of spatially incompatible 'large area statistics' and other limitations associated with indicators and related maps that portray the geography of need, development and sustainability in terms of an absolute, container view of space (Couclelis, 1991). The underlying mesoframe methodology - developed by the Council for Scientific and Industrial Research (CSIR) Built Environment unit (Naudé et al., 2007) - overcomes the problem of spatially incompatible 'large area statistics ' by re-scaling and assembling a variety of census, satellite imagery and other data sources in terms of a common set of mesoscale analysis units. This consists of 25000 irregularly shaped meso-zones (approximately $49 \mathrm{~km}^{2}$ or $7 \mathrm{~km}$ by $7 \mathrm{~km}$ in size). The demarcation of meso-zones was determined using various types of boundaries (political, economic and biophysical). In particular, they were demarcated so as to nest within important administrative and physiographic boundaries, and to be connected to a digital road network for South Africa. A primary consideration was that these boundaries should correspond with travel barriers such as rivers and 'breaklines ' between sparsely and densely populated areas.

The data rescaling methodology is similar to the method that was used to derive the $1 \mathrm{~km}$ resolution Global Landscan population database (developed by the USA's Oak Ridge National Laboratory), where large area census information was disaggregated on the basis of fine-grained remote sensing information (Bhaduri et al., 2007). The main difference is that a much coarser, irregular, meso-scale grid is used, thereby reducing high data transfer and computation requirements, as well as improving the capability to model inter-zonal linkages and spatial interactions. Linking back to the early distinction between absolute and relative conceptions of space, this enhances the capability to build models representing the relative or relational characteristics of space (Harvey, 1996).

\section{Study area - the Inkomati Water Management Area}

The Inkomati River Basin covers an area of $45779 \mathrm{~km}^{2}$, largely within the Mpumalanga Province of South Africa, and extending into Swaziland and Mozambique. The topography of the area consists of the flat Mozambican coastal plains in the east; flat to undulating terrain immediately west of this ('lowveld'), much of which falls within the Kruger

National Park (the Lebombo Mountains separate the lowveld from the coastal plains); and 
an escarpment (the Mpumalanga Drakensberg) rising to an inland plateau ('highveld') further to the west.

Almost the entire Basin falls within a summer rainfall area, with cold but dry winters. Only the western mountainous areas experience year-round precipitation, in the form of orographic rain and mist. The main rivers draining the Basin are the Komati, Lomati, Crocodile, Elands, Kaap, Sabie, and Sand (Figure 1). These rise in the mountainous areas to the west and south of the Basin, and generally drain eastwards into the Inkomati River, which enters the sea at Maputo Bay in Mozambique. The vegetation in the South African portion of the Basin is dominated by mesic highveld grasslands in the western high-lying areas (annual precipitation varies between 650 and $1490 \mathrm{~mm}$ ) and savanna/woodlands in the lowveld bioregion (between 350 and $1200 \mathrm{~mm} \mathrm{yr}^{-1}$ ) (Mucina and Rutherford, 2006).

The main income-generating activities within the South African portion of the Basin (the Inkomati Water Management Area) include tourism, commercial irrigation, forestry and mining. The sectoral water-use profile of the management area is summarised in Table 1. Note that the commercial irrigation sector covers only $3 \%$ of the Inkomati Water Management Area (WMA), but accounts for $51 \%$ of the total water use. The intensity with which water and land resources are exploited has led to the natural capital of the region being substantially depleted and degraded. For example, the Inkomati WMA currently experiences a water deficit of about $12 \%$ of its total requirements (Department of Water Affairs and Forestry, 2004), due to excessive water extraction for irrigation, as well as water pollution from chemicals (fertilizers and herbicides) being washed into rivers. Rates of land degradation and land use change are also on the increase (Van der Zaag and Vaz, 2003; Department of Water Affairs and Forestry, 2004; Sengo et al., 2005; LeMarie et al., 2006; Soppe et al., 2006). 


\section{A method for overcoming spatial data incompatibilities}

We illustrate our methodology using agricultural-economic census data as an example of a socio-economic data set, and land cover data as an example of a biophysical data set. The 2002 Census of Agricultural Provincial Statistics (Statistics South Africa, 2002) is the most recent and comprehensive national agricultural production data set available in South Africa. It presents agricultural production data at the relatively coarse magisterial district scale, and as a result the exact spatial locations of agricultural commodities within the magisterial districts are not geo-referenced. By contrast, the South African National Land Cover Database, as described by Fairbanks et al. (2000) and revised for the 2000 version (Agricultural Research Council and Council for Scientific and Industrial Research, 2000; Standards South Africa, 2004), represents South Africa in 49 land cover categories based on satellite imagery at a $900 \mathrm{~m}^{2}$ resolution. The resolution is therefore significantly higher than the agricultural census data.

Furthermore, we use the allocation of bulk water supplies between commercial irrigators as an example of a resource management problem. This example illustrates data incompatibility problems, the need for a flexible approach to overcome these issues, and the potential benefits that can realised from overcoming these problems. The allocation of bulk water supplies is based on both socio-economic and biophysical data that varies across space and time. Since the spatially relevant forms of these data are subject to the problems described in Section 1, it is difficult for decision makers to determine the spatial trade-offs involved when allocating water between spatially disparate agricultural water users.

A three-staged approach for integrating socio-economic and biophysical data is presented below. The first stage involves aligning coarse-scale agricultural-economic census data to 
fine-scale geo-referenced land cover data. The second stage involves estimating the gross economic values of water used in commercial crop production, and integrating these with existing land cover categories. The third and final step involves manipulating and presenting the estimated economic values spatially within a GIS environment. Each of these steps is described in detail below, while the entire process of converting the highly aggregated, spatially inexplicit agricultural census data into a spatially explicit GIS data layer is depicted graphically in Figure 2.

\subsection{Step 1: Aligning agricultural-economic census data with land cover categories}

This step involves disaggregating data from the 2002 Census of Agricultural Provincial Statistics (Statistics South Africa, 2002) from the coarse magisterial district scale to the much finer scale for which land cover data are available $\left(900 \mathrm{~m}^{2}\right)$. This step is represented by the arrow labelled ' 1 ' in Figure 2.

The approach to disaggregate and geo-reference the agricultural-economic census data involved:

1) Determining the magisterial districts ${ }^{2}$ that fall wholly or partly within the Inkomati Water Management Area (WMA), and their associated areas (Table 2). For those magisterial districts only partly within the WMA, it was necessary to estimate areaweighted averages of all relevant variables based on the proportion of the area of these magisterial districts that fall within the study area.

\footnotetext{
${ }^{2}$ The names of the magisterial districts are as per the 2002 Agricultural Census.
} 
2) Identifying the land cover categories that most closely represent the crop types that occur in each magisterial district ${ }^{3}$. For illustration purposes and to ensure clarity, we limited this to the commercial agricultural crops, which are adequately represented by five of the 49 land cover categories. However, these do not differentiate between crops. For example, the category 'cultivated, permanent, commercial, irrigated' includes orchards of various fruit (see Table 4).

3) Estimating the area of each of the selected land cover categories within the magisterial districts (Table 3). Since the 'cultivated, permanent, commercial, dryland' land cover category is represented by only 67 ha in the study area, this category is excluded from further analysis.

\subsection{Step 2: Economic value derived from water per land cover category}

The SAPWAT simulation model (Crosby, 1996) was used to estimate water requirements for different commercial crops. SAPWAT is designed to simulate crop water requirements (accounting for rainfall) under different climatic scenarios. The procedure that SAPWAT employs uses long-term (at least 50 years) weather station data and Food and Agriculture Organisation (FAO) guidelines on crop water requirements (Allen et al., 1998) to estimate water requirements for different irrigation systems that maintains field capacity in a selected target area (Van Heerden et al., 2001). The SAPWAT model can be calibrated to an area by selecting the closest weather station data set provided in the model (SAPWAT includes long term weather data for 5126 weather stations worldwide and can therefore be calibrated for any area in the world). Once calibrated to the climatic conditions in the area,

\footnotetext{
${ }^{3}$ For example, mangoes are best described by the "cultivated permanent commercial irrigated" land cover category whereas tomatoes fall best within the "cultivated temporary commercial irrigated" land cover category.
} 
a crop is selected and simulations run to estimate the crop's 'typical' water use profile (given a suitable irrigation system) over an irrigation season.

Since each of the four selected land cover categories consists of numerous commercial crops, and because SAPWAT can only simulate water requirements for a single crop at a time, it was necessary to select representative crops (we decided on a maximum of three) based on the size of the cultivated areas of each crop within each land cover category, per magisterial district (Table 4). Within the 'cultivated, temporary, commercial, irrigated' category, a distinction is made between 'field crops' and 'vegetables' because they have significantly different water-use profiles. In such cases, SAPWAT was run for each crop, and the outputs were combined for further analysis. The estimated total annual water use per land cover category as listed in Table 5 are area-weighted sums of the SAPWAT generated values for the representative crops (Table 4) of each land cover category per magisterial district. For example, the data indicate that the land cover category 'cultivated, permanent, commercial, irrigated' in the Barberton Magisterial District has bananas, citrus and mangoes as representative crops, which use an area-weighted average of $1704 \mathrm{~mm}$ ha-1 yr-1 of water.

The average gross economic value per ha per land cover category was then estimated by dividing the total gross farm income per land cover category (aggregation of the crops within that category) by the total hectares of that land cover category per magisterial district (as presented in Table 3). The economic values derived from agricultural water use (South African Rands ${ }^{4}$ per $\mathrm{m}^{3}$ ) per land cover category were estimated by dividing the total gross farm income per land cover category by the water use per category. Both estimates are presented in Table 6 for each land cover category and magisterial district.

\footnotetext{
${ }^{4} 1$ USD $=$ approximately 10 ZAR (South African Rands).
} 
We are aware that these are not fully inclusive estimates of the value of water. Water is not the only input in agricultural production processes, and the value of water changes depending on its scarcity relative to that of other inputs, while the costs of supplying the water have also not been accounted for. It was not the aim of this paper, however, to provide a fully inclusive estimate of the value of water, and the estimates are adequate as relative values to inform water allocation decisions.

\subsection{Step 3: Geo-spatial representation of the economic value derived from water used in irrigation agriculture}

The South African Geo-spatial Analysis Platform (GAP) (Council for Scientific and Industrial Research et al., 2007), described in Box 1, was used to spatially present the economic values estimated in Step 2 (Section 3.2). The GAP can be used as a generic, standardised unit to spatially represent socio-economic data in South Africa, as it includes a zonal database of key socio-economic, demographic and land cover variables. Although the data with which the database is populated is specific to South Africa, the GAP methodology could similarly be applied elsewhere.

To spatially represent the newly created data layer comprising of economic value estimates of Table 6 , it had to be aggregated to the meso-zone scale $\left(49 \mathrm{~km}^{2}\right.$, the spatial unit used by the GAP). This aggregation step involved overlaying the land cover data with the mesozones (already a GIS data layer) (see arrow '2' in Figure 2). The economic value estimates could then be represented spatially at a meso-zone scale. We present only one example (the Barberton Magisterial District, which is the darker shaded area seen in Figure 1) in Figure 
3, which shows the economic values of water, derived from its productive use in sugarcane ${ }^{5}$ (Figure 3A) and other irrigated commercial crops (Figure 3B).

\section{Discussion}

The significance of the methodology developed in this study lies in its ability to increase the resolution at which data on the economic value generated by the use of natural resources (in this case irrigation water) is presented, in this case from coarse magisterial district scale to the relatively fine $\left(49 \mathrm{~km}^{2}\right)$ meso-zone scale. This enables more efficient allocations of irrigation water within magisterial districts (although we acknowledge that allocation decisions are driven by various criteria apart from economic values). Water allocation decision-makers are therefore in a stronger position to justify both intra- and inter-district re-allocations. The method also facilitates the identification of specific areas within magisterial districts (on a meso-zone scale) to serve as focal points for intervention on key issues, such as rural to urban re-allocations (Gutman, 2007; Kroeger and Casey, 2007).

The method also has potential to overcome problems related to the different boundaries for which socio-economic and biophysical data are reported. For example, the spatial representations of the economic values of water as used in the irrigation sector could be overlaid with other biophysical data layers, including runoff, rainfall, land degradation, temperature, and soil and vegetation types. This would improve the information available for water allocation decision making, which would enable more efficient and equitable water allocations amongst users. For example, the inequitable (and possibly inefficient)

\footnotetext{
${ }^{5}$ Sugar cane is presented as a separate land cover category.
} 
allocation of water resources away from rural areas (where they are generated) towards urban/developed areas could potentially be further interrogated and communicated using this methodology (Gutman, 2007; Kroeger and Casey, 2007).

We therefore believe that this meta-modelling approach can add value to resource allocation decision-making processes in overcoming spatially-dependent socio-economic and regional planning challenges, because the overlaying of socio-economic and biophysical data layers can assist in the prioritisation of interventions for resource-stressed areas. It can also be used to communicate the environmental implications of existing distributions of social and economic activities (Bockstael, 1996; Eade and Moran, 1996; Deacon et al., 1998; Irwin and Geoghegan, 2001; Bateman et al., 2002; Lant et al., 2005; Sanchirico and Wilen, 2005; Hein et al., 2006). The proposed method could be applied in any region or country where the required data is available.

It is recognised, however, that numerous limitations still exist, warranting further research. Some suggestions for further research include: improving socio-economic data collection so as to be more compatible with biophysical data; developing statistical methods for interrogating spatial correlations between socio-economic and biophysical variables found using this method; and developing techniques for appraising links between ecosystem integrity and economic values under a range of socio-economic scenarios. 


\section{Acknowledgements}

We thank our colleague Andries Naudé for providing the description of the South African Geospatial Analysis Platform and the anonymous reviewers who provided valuable comments on an earlier version of the paper.

\section{References}

Agricultural Research Council, Council for Scientific and Industrial Research, 2000. National Land Cover database and spatial data for 2000. Agricultural Research Council and Council for Scientific and Industrial Research, Pretoria.

Allen, R., Pereira, L.S., Raes, D., Smith, M., 1998. Crop evapotranspiration: Guidelines for computing crop water requirements., Rome, FAO Irrigation and Drainage Paper No: 56.

Anselin, L., 1988. Spatial Econometrics:Methods and Models. Dordrecht, The Netherlands: Kluwer Academic Publishers.

Bateman, I.J., Jones, A.P., Lovett, A.A., Lake, I.R., Day, B.H., 2002. Applying Geographical Information Systems (GIS) to environmental and resource economics. Environmental and Resource Economics 22: 219-269, 2202. 22, 219-269.

Bhaduri, B., Bright, E., Coleman, P., 2007. LandScan USA: A high-resolution geospatial and temporal modeling approach for population distribution and dynamics. . GeoJournal 69, 103-117.

Blignaut, J., Marais, C., Rouget, M., Mander, M., Turpie, J., Preston, G., Philip, K., Du Plessis, L., Klassen, T., Tregurtha, N., 2008. Making markets work for people and the environment: Combating poverty and environmetal degredation on a single budget while delivering real services to real people. Research paper commissioned by: The Second Economy Strategy Project, en initiative of the Presidency, Pretoria, unpublished.

Bockstael, N.E., 1996. Modelling Economics and Ecology: The Importance of a Spatial Perspective. American Journal of Agricultural Economics 78, 1168-1180.

Bruggeman, D.J., Jones, M.L., Lupi, F., Scribner, K.T., 2005. Landscape equivalency analysis: Methodology for estimating spatially explicit biodiversity credits. Environmental Management 36 (4), 518-534.

Costanza, R., 2000. Social goals and the valuation of ecosystem services. Ecosystems 3, 3-10.

Costanza, R., Daly, H.E., 1992. Natural capital and sustainable developement. Conservation Biology 6 (1), 37-46.

Couclelis, H., 1991. Requirements for planning-relevant GIS: A spatial perspective. Papers in Regional Science 70, 9-19. 
Council for Scientific and Industrial Research, The Presidency, Department of Science and Technology, 2007. Geospatial analysis platform: Incorporating South African mesoframe (Version 2). CSIR, Pretoria.

Crosby, C.T., 1996. SAPWAT - A computer program for estimating irrigation requirements in Southern Africa. Water Research Commission, Pretoria, 379/1/96.

Curtis, A., Byron, I., McDonald, S., 2003. Integrating spatially referenced social and biophysical data to explore landholder responses to dryland salinity in Australia. Journal of Environmental Management 68, 397 - 407.

Deacon, R.T., Brookshire, D.S., Fisher, A.C., Kneese, A.V., Kolstad, C.D., Scrogin, D., Smith, V.K., Ward, M., J., W., 1998. Research trends and opportunities in environmental and natural resource economics. Environmental and Resource Economics 11 (3-4), 383-397.

Department of Water Affairs and Forestry, 2004. Inkomati Water Management Area: Internal strategic perspective. Tlou \& Matji Engineering and Management Services (Pty) Ltd, Pretoria, PWMA 05/000/00/0303.

Eade, J., Moran, D., 1996. Spatial economic valuation: Benefits transfer using geographical information systems. Journal of Environmental Management 48, 97-110.

Fairbanks, H.H.K., Thompson, M.W., Vink, D.E., Newby, T.S., Van den Berg, H.M., Everard, D.A., 2000. The South African land cover characteristics database: A synopsis of the landscape. South African Journal of Science 96, 69-82.

Freeman, A.M., 1979. The Benefits of Environmental Improvements: Theory and Practice. Baltimore: Johns Hopkins University Press.

Geoghegan, J., Cortina-Villar, S., Klepeis, P., Macario-Mendoza, P., Ogneva-Himmelberger, Y., Chowdhury, R.R., Turner, B.L., Vance, C., 2001. Modelling Tropical Deforestation in the Southern Yucatan Peninsular Region: Comparing Survey and Satellite Data. Agriculture, Ecosystems and Environment 85, 25-46.

Goodstein, E.S., 1999. Economics and the environment. Prentice Hall Publishers: New Jersey.

Gutman, P., 2007. Ecosystem services: Foundations for a new rural-urban compact. Ecological Economics 62 (3-4), 383-387.

Harvey, D., 1996. Justice, Nature and the Geography of Difference. Blakewell: Oxford.

Heal, G., 2000. Valuing Ecosystem Services. Ecosystems 3, 24 - 30.

Hean, R., Cacho, O.J., Nordblom, T., Hume, I., 2006. Spatially-explicit modelling for salinity management at the catchment level. 50th Conference of the Australian Agricultural and Resource Economics Society. Sydney, Feb 2006.

Hein, L., Van Koppen, K., De Groot, R.S., Van Ierland, E.C., 2006. Spatial scales, stakeholders and the valuation of ecosystem services. Ecological Economics 57, 209-228.

Herr, A., 2007. Data Integration Issues in Research Supporting Sustainable Natural Resource Management. Geographical Research 45 (4), 376 - 386.

Irwin, E.G., Geoghegan, J., 2001. Theory, data, methods: Developing spatially explicit economic models of land use change. Agriculture, Ecosystems \& Environment 85 (1-3), 7-24. 
Jakeman, A.J., Letcher, R.A., 2003. Integrated assessment and modelling: features, principles and examples for catchment management. Environmental Modelling \& Software 18, 491-501.

Kroeger, T., Casey, F., 2007. An assessment of market-based approaches to providing ecosystem services on agricultural lands. Ecological Economics 64, 321-332.

Lant, C., Kraft, S., Beaulieu, J., Bennett, D., Loftus, T., Nicklow, N., 2005. Using GIS-based ecological-economic modeling to evaluate policies affecting agricultural watersheds. Ecological Economics 55, 467-484.

LeMarie, M., Van der Zaag, P., Menting, G., Baquete, E., Schotanus, D., 2006. The use of remote sensing for monitoring environmental indicators: The case of the Inkomati estuary, Mozambique. Physics and Chemistry of the Earth 31, 857-863.

Lovett, A.A., Bateman, I.J., 2001. Economic analysis of environmental preferences: Progress and prospects. Computers, Environment and Urban Systems 25, 131-139.

Mucina, L., Rutherford, M.C., 2006. The vegetation of South Africa, Lesotho and Swaziland., Strelitzia, South African National Biodiversity Institute, Pretoria.

Munasinghe, M., 2002. The sustainomics trans-disciplinary meta-framework for making development more sustainable: Applications to energy issues. International Journal of Sustainable Development 5 (1), 125-182.

Naudé, A.H., Badenhorst, W., Zietsman, H.L., Van Huyssteen, E., Maritz, J., 2007. Technical overview of the mesoframe methodology and South African Geospatial Analysis Platform. CSIR, Pretoria.

Reyers, B., Wise, R.M., Guo, C., Midgley, G.F., under review. Determining the costs of conservation responses to climate change: a case study from a global biodiversity hotspot. Frontiers in Ecology and Evolution.

Ruth, M., 2006. A quest for the economics of sustainability and the sustainability of economics. Ecological Economics 56, 332-342.

Sanchirico, J.N., Wilen, J.N., 2005. Optimal spatial management of renewable resources: Matching policy scope to ecosystem scale. Journal of Environmental Economics and Management 50, 23-46.

Sengo, D.J., Kachapila, A., van der Zaag, P., Mul, M., Nkomo, S., 2005. Valuing environmental water pulses into the Incomati estuary: Key to achieving equitable and sustainable utilisation of transboundary waters. Physics and Chemistry of the Earth 30, 646 - 657.

Sinden, J.A., Griffith, G., 2007. Combining economic and ecological arguments to value the environmental gains from control of 35 weeds in Australia. Ecological Economics 61, 396-408.

Soppe, R., Hellegers, P., Perry, C., Boon, D., Bastiaanssen, W., De Wit, M., 2006. Combining Remote Sensing and Economic Analysis to Assess Water Productivity: A demonstration project in the Inkomati Basin. Water Watch and LEI, Wageningin and Den Haag, Netherlands, unknown.

Standards South Africa, 2004. South African National Standard (SANS) 1877:2004 - A standard land-cover classification scheme for remote-sensing applications in South Africa. Edition 1. . Standards South Africa, Pretoria.

Statistics South Africa, 2002. Census of agriculture provincial statistics 2002: Mpumalanga financial and production statistics. Statistics South Africa, Pretoria, 11-02-09 (2002). 
Tobias, D., Mendelsohn, R., 1991. Valuing ecotourism in tropical forest reserve. Ambio 20, 91-93.

Turner, R.K., Paavola, J., Cooper, P., Farber, S., 2003. Valuing nature: Lessons learned and future research directions. Ecological Economics 46, 496-510.

Van Delden, H., Luja, P., Engelen, G., 2007. Integration of multi-scale dynamic spatial models of socio-economic and physical processes for river basin management. Environmental modelling and Software 22, 223-238.

Van der Zaag, P., Vaz, A.C., 2003. Sharing the Incomati waters: Cooperation and competition in the balance. Water Policy 5, 349-368.

Van Heerden, P.S., Crosby, C.T., Crosby, C.P., 2001. Using Sapwat to estimate water requirements of crops in selected irrigation areas managed by the Orange - Vaal and Orange Riet water users association. Water Research Commission, Pretoria, TT 163/01.

Wadsworth, R., Treweek, J., 1999. Geographical Information Systems for Ecology. An Introduction. Harlow: Longman.

Wilson, M.A., Howarth, R.B., 2002. Discourse-based valuation of ecosystem servcies: establishing fair outcomes through group deliberation. Ecological Economics 41, 431-443. 


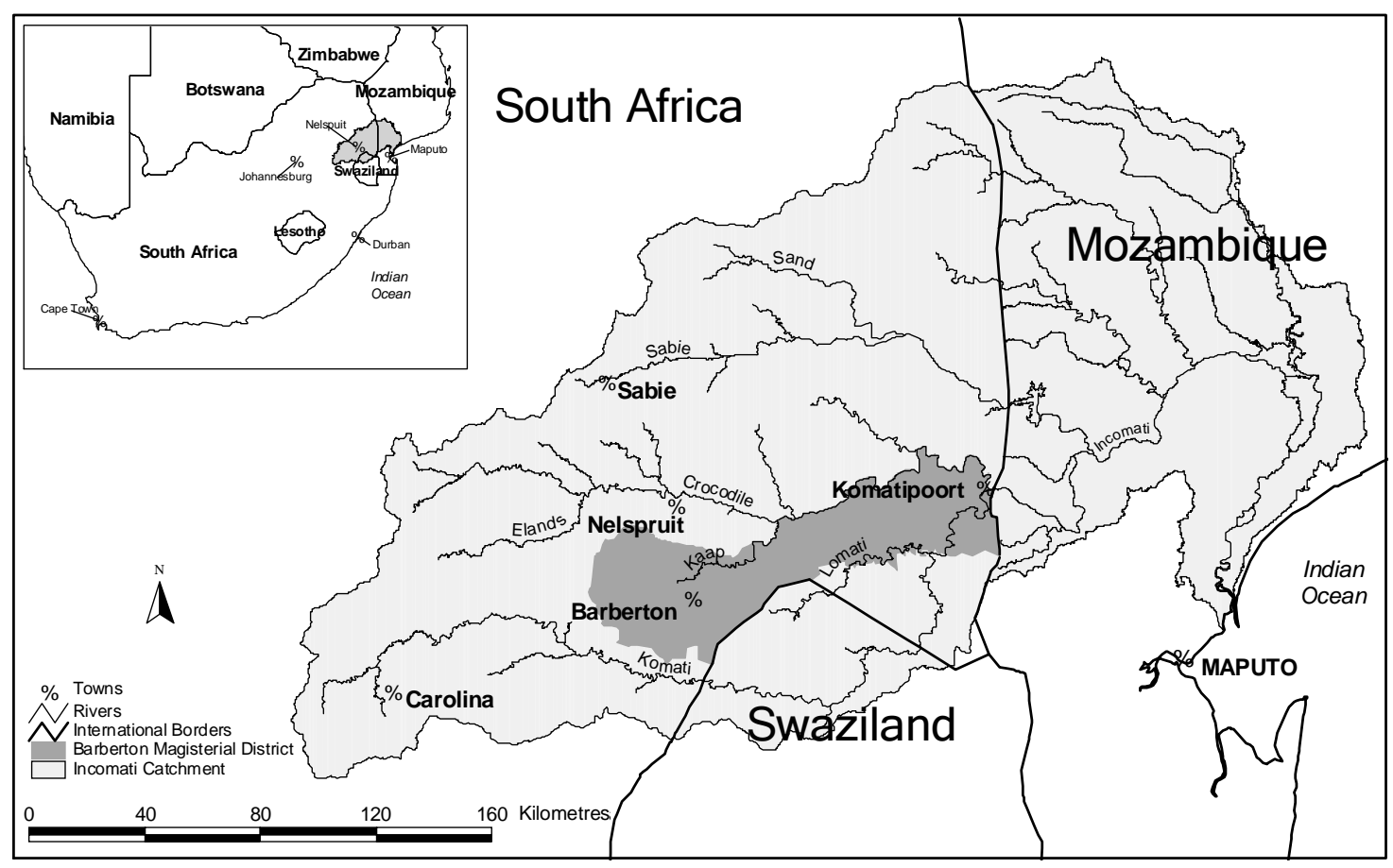

Figure 1: The Inkomati River Basin in southern Africa. The portion of the Basin occurring within South Africa is known as the Inkomati Water Management Area. The extent of the Barberton Magisterial District (which includes the towns of Barberton and Komatipoort) is shown by the darker shaded area. 


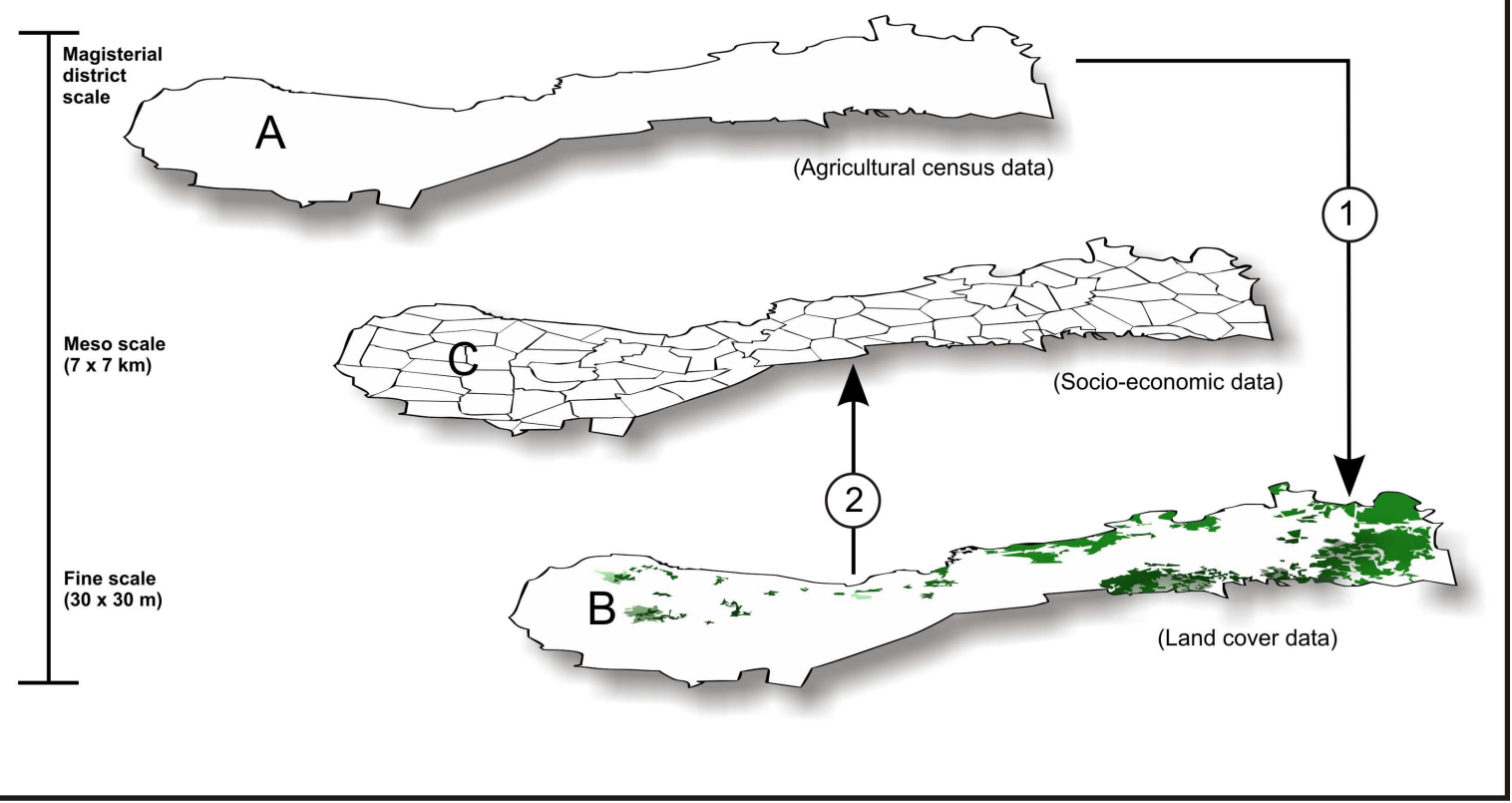

Figure 2: Graphical representation of the conversion of agricultural census data for the Barberton Magisterial District $\left(3,693 \mathrm{~km}^{2}\right)$, a part of the Inkomati Water Management Area, into a spatially explicit GIS layer. Agricultural census data (A), although collected on a farm-by-farm basis, are only published at the rather coarse magisterial district scale. Land cover data (B) are collected at a resolution of $900 \mathrm{~m}^{2}$ and presented in 49 categories. Socio-economic data (C), such as population, economic activity and poverty levels, are available in South Africa at a meso-scale $\left(49 \mathrm{~km}^{2}\right.$, see Box 1). The agricultural census data were reclassified and joined to the corresponding land cover category making it spatially explicit (arrow 1, representing step 1, described in Section 3.1). The result can now be combined with the socio-economic data (arrow 2, representing step 3 described in Section 3.3). 

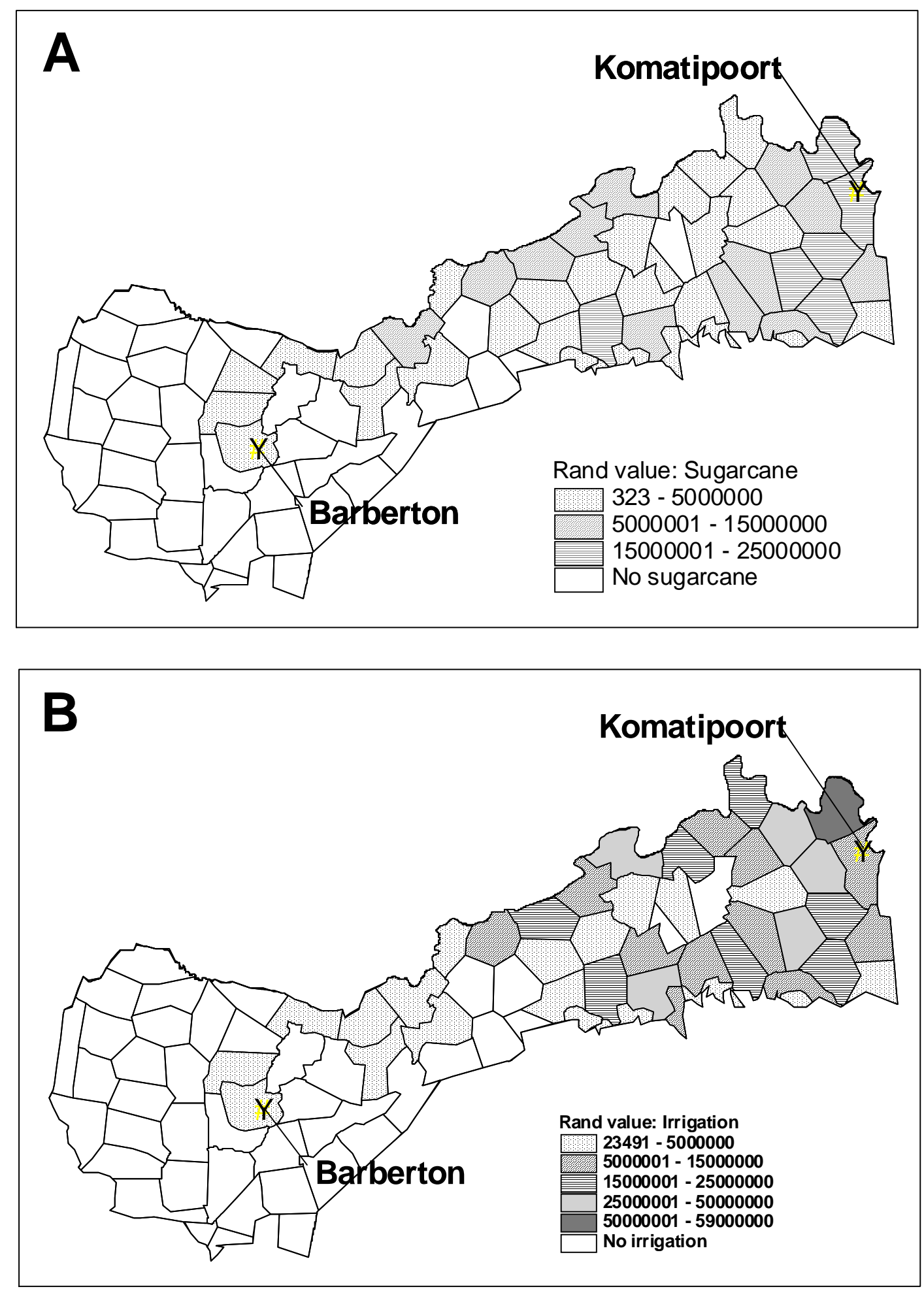

Figure 3: The economic value derived from irrigation water used in growing (A) sugarcane and (B) other irrigated commercial crops (including both permanent and temporary), showing the relevant meso-zones within the Barberton Magisterial 
District (part of the Inkomati Water Management Area). The main towns of Barberton and Komatipoort are also shown.

Table 1: Water requirements per economic sector within the Inkomati Water Management Area as a proportion of total demand

\begin{tabular}{lrrrrr}
\hline Sector & Water required $\mathrm{a}^{\mathrm{a}}\left(\mathrm{Mm}^{3} \mathrm{yr}^{-1}\right)$ & Proportion $(\%)$ & Water availability $\left(\mathrm{Mm}^{3} \mathrm{yr}^{-1}\right)$ & \\
Irrigation & 600 & $51.0 \%$ & 947 & Surface water & Natural \\
Urban & 63 & $5.4 \%$ & 22 & Ground water & resource \\
Rural & 27 & $2.3 \%$ & 53 & Irrigation & Usable return \\
Mining & 24 & $2.0 \%$ & 7 & Urban & flow \\
Forestry & 139 & $11.8 \%$ & 11 & Mining and bulk & \\
International & 109 & $9.3 \%$ & 0 & & \\
Transfer out & 214 & $18.2 \%$ & 0 & & \\
Total & 1176 & $100.0 \%$ & 1040 & & \\
\hline
\end{tabular}

Source: (Department of Water Affairs and Forestry, 2004)

${ }^{\text {a }}$ Expressed as impact on the 1:50 year yield. $\mathrm{Mm}^{3} \mathrm{yr}^{-1}$ refers to million cubic metres per year. 
Table 2: Magisterial districts wholly or partly within the Inkomati Water Management Area ${ }^{1}$

\begin{tabular}{lrr}
\hline Magisterial district & Total area $\left(\mathbf{h a}^{-1}\right)$ & $\begin{array}{r}\text { Proportion of magisterial } \\
\text { district area within the } \\
\text { study area (\%) }\end{array}$ \\
Barberton & 369329 & $100 \%$ \\
Belfast & 172062 & $57 \%$ \\
Carolina & 379963 & $98 \%$ \\
Ermelo & 36437 & $13 \%$ \\
Lydenburg & 66309 & $100 \%$ \\
Nelspruit & 218330 & $97 \%$ \\
Nkomazi & 131216 & $67 \%$ \\
Pilgrim's Rest & 586321 & $100 \%$ \\
Waterval-Boven & 98273 & $100 \%$ \\
White River & 407173 & \\
\hline
\end{tabular}


Table 3: Estimated extent of agricultural land cover categories per magisterial district within the Inkomati Water Management Area ${ }^{1}$

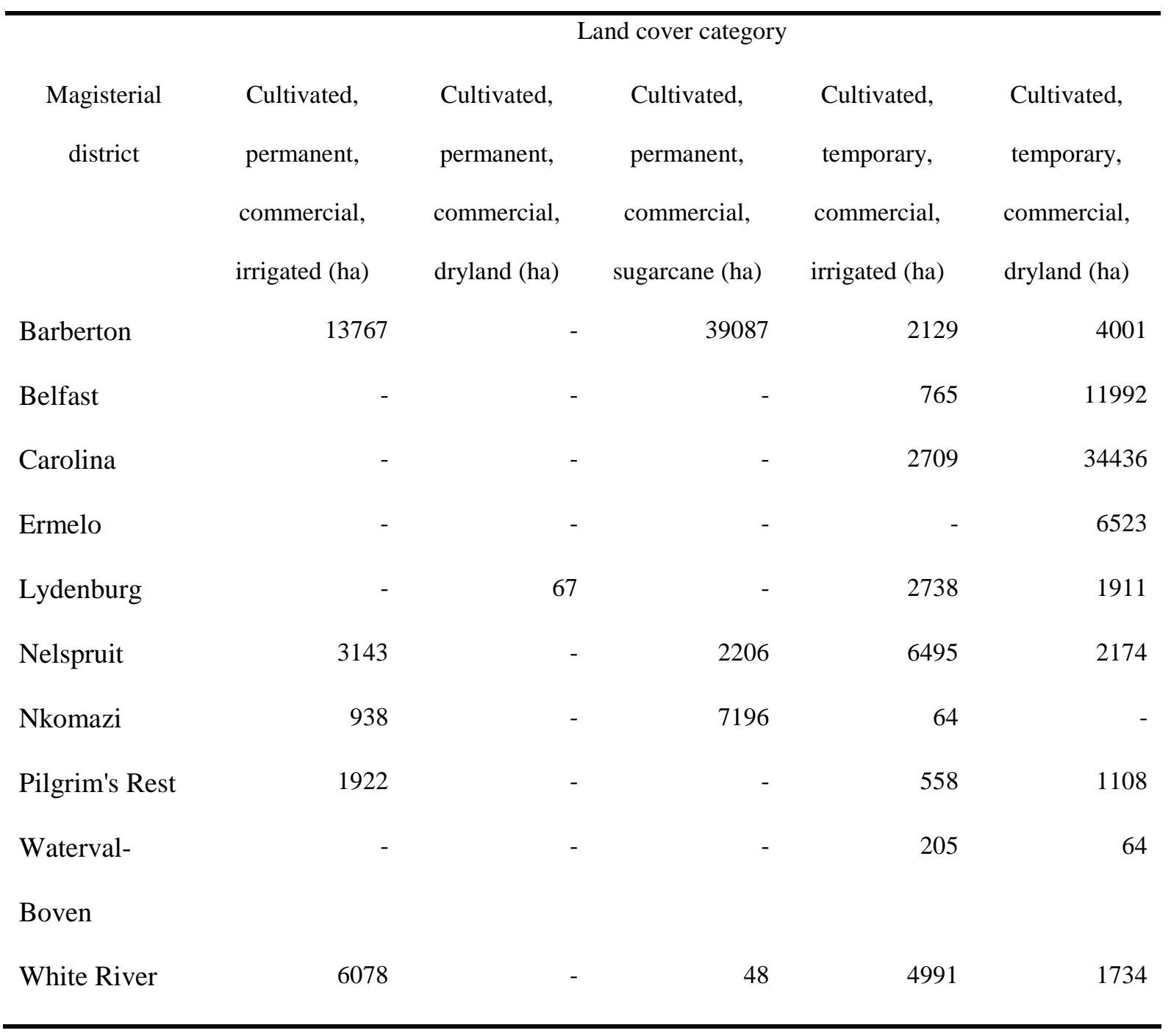


Table 4: Crops used to represent the agricultural land cover categories occurring in the magisterial districts within the Inkomati Water Management Area

\begin{tabular}{|c|c|c|c|c|c|}
\hline \multirow[b]{2}{*}{ Magisterial } & \multicolumn{5}{|c|}{ Land cover category } \\
\hline & Cultivated, & Cultivated, & Cultivated, & Cultivated, & Cultivated, \\
\hline \multirow[t]{4}{*}{ district } & permanent, & permanent, & temporary, & temporary, & temporary, \\
\hline & commercial, & commercial, & commercial, & commercial, & commercial, \\
\hline & irrigated & sugarcane & irrigated & irrigated & dryland \\
\hline & & & (field crops) & (vegetables) & \\
\hline Barberton & banana/ citrus/ & sugarcane & tobacco & tomato & maize \\
\hline & mango & & & & \\
\hline Belfast & - & - & maize & N/A & maize \\
\hline Carolina & - & - & maize/ soy & potato & maize \\
\hline Ermelo & - & - & - & - & maize \\
\hline Lydenburg & - & - & maize & potato & maize \\
\hline Nelspruit & citrus/ avocado & sugarcane & tobacco & sweet potato & maize \\
\hline Nkomazi & citrus & sugarcane & maize & N/A & - \\
\hline Pilgrim's Rest & banana & - & maize & beans & maize \\
\hline Waterval- & - & - & maize & beans & maize \\
\hline \multicolumn{6}{|l|}{ Boven } \\
\hline White River & banana/ avocado & sugarcane & tobacco & sweet potato & maize \\
\hline
\end{tabular}


Table 5: Estimated total annual water use per land cover category in each of the magisterial districts within the Inkomati Water Management Area

\begin{tabular}{|c|c|c|c|c|}
\hline \multirow[b]{2}{*}{$\begin{array}{c}\text { Magisterial } \\
\text { district }\end{array}$} & \multicolumn{4}{|c|}{ Land cover category } \\
\hline & $\begin{array}{l}\text { Cultivated, } \\
\text { permanent, } \\
\text { commercial, } \\
\text { irrigated }\left(\mathrm{mm} \mathrm{ha}^{-1)}\right.\end{array}$ & $\begin{array}{l}\text { Cultivated, } \\
\text { permanent, } \\
\text { commercial, } \\
\text { sugarcane }\left(\mathrm{mm} \mathrm{ha}^{-1)}\right.\end{array}$ & $\begin{array}{c}\text { Cultivated, } \\
\text { temporary, } \\
\text { commercial, } \\
\text { irrigated }\left(\mathrm{mm} \mathrm{ha}^{-1)}\right.\end{array}$ & $\begin{array}{c}\text { Cultivated, } \\
\text { temporary, } \\
\text { commercial, dryland } \\
\left(\mathrm{mm} \mathrm{ha}^{-1)}\right.\end{array}$ \\
\hline Barberton & 1704 & 2338 & 1010 & 472 \\
\hline Belfast & - & - & 844 & 559 \\
\hline Carolina & - & - & 857 & 494 \\
\hline Ermelo & - & - & - & 494 \\
\hline Lydenburg & - & - & 584 & 439 \\
\hline Nelspruit & 1693 & 2447 & 891 & 413 \\
\hline Nkomazi & 1834 & 2217 & 962 & - \\
\hline Pilgrim's & 1533 & - & 583 & 366 \\
\hline Rest & & & & \\
\hline $\begin{array}{l}\text { Waterval- } \\
\text { Boven }\end{array}$ & - & - & 540 & 439 \\
\hline White River & 1740 & 2325 & 831 & 447 \\
\hline
\end{tabular}


Table 6: Economic value generated from using water in crop production in each of the magisterial districts within the Inkomati Water Management Area ${ }^{1}$

\begin{tabular}{|c|c|c|c|c|c|c|}
\hline \multirow{6}{*}{$\begin{array}{c}\text { Magisterial } \\
\text { district }\end{array}$} & \multicolumn{6}{|c|}{ Land cover category } \\
\hline & \multirow{2}{*}{\multicolumn{2}{|c|}{$\begin{array}{l}\text { Cultivated, permanent, } \\
\text { commercial, irrigated }\end{array}$}} & \multirow{2}{*}{\multicolumn{2}{|c|}{$\begin{array}{l}\text { Cultivated, permanent, } \\
\text { commercial, sugarcane }\end{array}$}} & \multirow{2}{*}{\multicolumn{2}{|c|}{$\begin{array}{c}\text { Cultivated, temporary, } \\
\text { commercial, irrigated / dryland }\end{array}$}} \\
\hline & & & & & & \\
\hline & Economic & Economic & Economic & Economic & Economic & Economic value \\
\hline & value (ZAR & value & value (ZAR & value & value (ZAR & $\left(\mathrm{ZAR} \mathrm{m}^{-3}\right)$ \\
\hline & $\left.\mathrm{ha}^{-1}\right)$ & $\left(\mathrm{ZAR} \mathrm{m}^{-3}\right)$ & $\left.h a^{-1}\right)$ & $\left(\mathrm{ZAR} \mathrm{m}^{-3}\right)$ & $\left.\mathrm{ha}^{-1}\right)$ & \\
\hline Barberton & 36419 & 2.14 & 7511 & 0.32 & 10402 & 1.58 \\
\hline Belfast & - & - & - & - & 935 & 0.16 \\
\hline Carolina & - & - & - & - & 1171 & 0.23 \\
\hline Ermelo & - & - & - & - & 1504 & 0.30 \\
\hline Lydenburg & - & - & - & - & 1260 & 0.24 \\
\hline Nelspruit & 36726 & 2.17 & 9942 & 0.41 & 9423 & 1.22 \\
\hline Nkomazi & 27734 & 1.51 & 2133 & 0.10 & $-{ }^{a}$ & $-{ }^{a}$ \\
\hline Pilgrim's Rest & 2175 & 0.14 & - & - & 3829 & 0.87 \\
\hline Waterval-Boven & - & - & - & - & 1727 & 0.33 \\
\hline White River & 38944 & 2.24 & 9206 & 0.40 & 3810 & 0.52 \\
\hline
\end{tabular}

ZAR = South African Rands. 1 USD = approximately 10 ZAR

${ }^{\text {a }}$ Economic value generated in Nkomazi for the cultivated, temporary, commercial, irrigated/dryland category was too low to be registered by the Agricultural Census 